NBER WORKING PAPERS SERIES

\title{
LABOR MARKET SEGMENTATION THEORY: \\ RECONSIDERING THE EVIDENCE
}

\author{
William T. Dickens
}

Kevin Lang

Working Paper No. 4087

\section{NATIONAL BUREAU OF ECONOMIC RESEARCH \\ 1050 Massachusetts Avenue \\ Cambridge, MA 02138 \\ June 1992}

We would like to thank the usual group of little people without whose help this would have been done much sooner. We would also like to acknowledge the generous research support of the Institute of Industrial Relations at U.C. Berkeley. This paper is part of NBER's research program in Labor Studies. Any opinions expressed are those of the authors and not those of the National Bureau of Economic Research. 


\title{
LABOR MARKET SEGMENTATION THEORY: RECONSIDERING THE EVIDENCE
}

\begin{abstract}
$\underline{\text { ABSTRACT }}$
We argue that Labor Market Segmentation theory is a good alternative to standard views of the labor market. Since it is sometimes argued that labor market segmentation theory is untestable, we first consider the uses of theory and the attributes of a good theory. We then argue that labor market segmentation has these attributes. It is internally consistent and is based on plausible assumptions about behavior and technology. More significantly, many of the predictions of the theory have been tested and confiied. Further, from a dynamic view the theory has done quite well. When the theory has suggested new tests, far more often tban not the predictions have been validated. Labor market segmentation theory has had to make little recourse to post-hoc explanations for unexpected empirical results. In contrast, human capital theory has required a series of post-hoc rationalizations to explain a large and growing body of empirical work motivated by the labor market segmentation perspective. Finally, we consider the implications of labor market segmentation theory for the practice of labor economics. We argue that further exploration of the implications of the theory for unemployment, trade. industrial policy and income distribution will provide useful insights and further tests of the theory.
\end{abstract}

William T. Dickens

Department of Economics

University of California

Berkeley, CA 94720

and NBER
Kevin Lang

Department of Economics

Boston University

Boston, MA 02215

and NBER 
When asking questions about the labor market, particularly earnings determination, human capital theory is the most important tool in the economist's toolbox. However, there is an alternative -- labor market segmentation theory. Labor market segmentation was advanced as an alternative to human capital theory by several authors in the early 1970s. Following a brief period of popularity, it faded after influential critiques suggested that existing evidence did not differentiate between labor market segmentation and standard human capital theory (Wachter 1974, Cain 1976). In the last decade several important theoretical and empirical developments have generated a resurgence of interest in the theory.

We review these developments and conclude that labor market segmentation theory provides a good alternative to human capital theory and deserves an equivalent position in the economist's toolbox. When analyzing policy questions or when designing new explorations, economists should consider the implications of labor market segmentation theory. This opens a broad area of work --the application of labor market segmentation theory to several problems previously only analyzed from the standard perspective. We briefly consider some of these applications below. 
Since labor market segmentation has often been accused of being untestable, we begin with a discussion of epistemology. In the second section we describe the essential elements and common attributes of labor market segmentation theories. The third section briefly describes the theoretical foundations of labor market segmentation theory -- efficiency wage theory or the closely related literatures on rent sharing or rent extraction, The fourth and fifth sections present the evidence on labor market segmentation theory. In the fourth section we discuss the evidence on the extent and origin of inter-employer wage differences. In the fifth section we discuss explicit tests of dual market theory. The sixth section is an explicit reply to criticisms of some of our early work on dual market theory. In particular we return to the question of what makes a good theory and discuss our work in light of these criteria. The final section summarizes our arguments and briefly considers the implications of labor market segmentation theory for future work.

\section{What Is a Good Theory?}

Economists are frequently hostile to discussions of epistemology. Tjalling Koopmans is almost apologetic in the introduction to his famous essay on methodology (1957) as were two 
of his eminent predecessors in the field (Roy Harrod, 1938; Dennis Robertson, 1940). This hostility is unfortunate, because it significantly undermines our ability to assess the significance of hypothesis tests in economics.

Economists are frequently naive falsificationists, holding the view that a bad theory is one that has been proved wrong. Similarly, a good theory is one which could be proved false, has been subjected to testing and has not yet been demonstrated to be false. This view is often associated with Karl Popper but represents an oversimplification of his position. Naive falsificationism leads economists to look for 'definitive' tests of a theory. A 'good' test is one which could definitively falsify a theory. To be 'definitive,' a test must generate a result which is not explicable by the theory being tested. By the same logic, a 'good' theory is one for which a 'definitive' test can be developed.

This position would be laughable if it did not inform seminar discussions and presumably influence research and publication decisions. It is also the position which has allowed many economists to dismiss labor market segmentation theory as untestable. While economists are apt to envy the scientist's ability to generate crucial 
experiments, the truth is that experiments are deemed crucial only with the hindsight of history. Lakatos (1978, pp. 86-87) reports that

There were many experiments in the eighteenth century which were, as a matter of historico-sociological fact, widely accepted as 'crucial' evidence against Galileo's law of free fall, and Newton's theory of gravitation. In the nineteenth century there were several 'crucial experiments' based on measurements of light velocity which 'disproved' the corpuscular theory and which turned out later to be erroneous in the light of relativii theory. These 'crucial experiments' were later deleted from justificationist textbooks as manifestations of shameful short-sightedness or even of envy. (Recently they reappeared in some new textbooks, this time to illustratethe inescapable irrationality of scientific fashions.) However, in those cases in which ostensibly 'crucial experiments' were indeed later borne out by the defeat of the programme, historians charged those who resisted them with stupidity, jealousy, or unjustified adulation of the father of the research programme in question.

Experiments or hypothesis tests cannot be crucial, because there is no theory which remains free of anomalies for long. Similarly, there is no result which cannot be explained by some modification of the theory which its proponents will claim is minor.'

\footnotetext{
The flat earth theory still has proponents who are adept at explaining why apparently contradictory evidence really conforms with the theory. As recently as fifteen years ago an organization calling itself the "Defenders of the Geocentric
} 
If we can not expect to reject theories with decisive tests, how then should we decide between theories? One plausible answer is that we should ask which theory is compatible with a wider range of "known facts' about the world. While attractive, this gives too much weight to theories which have been around for a long time. We can ask the question if you wanted to go to San Francisco would you prefer to be on a train 1000 miles or 1500 miles away. Everything else equal we would probably prefer the train which was closer. However, if the train which is farther away is moving twice as fast, we may get to San Francisco sooner on that train. In short, as in many topics economists discuss, we care not only about levels but also about derivatives. Indeed, since we expect to do economic research for a long time, the rate at which a research program is progressing and not its abilii to explain known 'facts is of primary importance. Thus, the true test of a theory or research program is dynamic. A good theory generates excess empirical content which tends to be corroborated and expands the range it can explain without large adjustments. A

Universe" published their own Newspaper The Bravhian Debater, which offered rationalizations of their view. 
regressive program is one which is continually being altered in the face of contradictory evidence. ${ }^{2}$

In our assessment, we, of course, do not ignore the importance of other criteria for assessing economic theories such as their simplicity (Occam's razor) or their mathematical elegance. These aspects of theories influence their treatment in other disciplines, and affect our judgment of economic theories as well.

We will argue that in recent years labor market segmentation theory has been a very progressive research program. In contrast, human capital theory has required frequent modification to account for the empirical regularities generated by the labor market segmentation research program.

${ }^{2}$ Even this criteria (most often identified with Imre Lakatos) has its critics. Paul Feyerabend, for example, argues that many research programs now viewed as progressive have had regressive periods and that it is inappropriate to prefer one over another on the basis of its past performance. We accept the point that second and higher derivatives matter in determining who will get where they are going first. However, in the absence of information on higher order derivatives we still prefer the train that it appears will arrive first projecting current rates. 
What Is Labor Market Segmentation Theory?

We identify two crucial elements of segmented labor market theory. First, the labor market can be usefully thought of as being made up several distinct segments with different rules for wage determination and employment policies. Second, access to jobs in at least some sectors at some times is limited in the sense that more people want jobs than there are jobs offered. Thus there may be queuing for these jobs either in the form of unemployment or job queues among employed workers or both.

While it is easy to state that labor market segmentation theory implies distinct segments, just what is meant by 'distinct segments' is more difficult. Minimally, a number of important characteristics of the wage determination mechanism and the employment relation must be correlated so that segments can be characterized as regions in a space with dimension significantly smaller than the space of characteristics. In the extreme, dual market theory has been interpreted by some as implying that a wide range of job characteristics are all highly correlated so that jobs can be arrayed along one dimension and described adequately by their position along that dimension.

Many tests of dual market theory have operationalized the concept of segment with particular reference to the wage determination 
mechanism. Most of these studies find that there is a difference between the wage determination mechanisms in the primary and secondary sector. Further, the differences are in accord with the descriptive literature on labor market segmentation. We will discuss these findings in greater detail below.

This aspect of the research helps to establish that labor market segmentation theory provides a good description of the income distribution and is therefore of heuristic importance. Although summarizing many characteristics of a job by its location in some classification system may be useful, it does not challengethe application of human capital theory to labor market problems. The reasons for segmentation may be important for understanding the form of the income distribution, but segmentation, as such, does not imply any market failure. Thus, Heckman and Sedlacek (1986) estimated a model of a segmented labor market consistent with a human capital view, and Heckman and Hotz (1986) propose such an interpretation for their finding that two equations fii the Panamanian income distribution better than one. The more fundamental criticism of human capital theory implied by labor market segmentation theory is that labor markets do not clear - that access to some sectors is subject to nonprice rationing. 
All the early writers on labor market segmentation theory identified limited mobility among sectors as an important aspect of the theory, More significantly, they argued that there is a hierarchy of sectors with access to the highest paying being the most difficult. Critics of labor market segmentation theory used the fact that during the economic expansion of the 1960s blacks were more likely to move into high wage jobs than whites as evidence against reduced mobility (Schiller 1977). Smith (1989) revives this argument by showing that earnings rise more rapidly with experience among blacks than among whites. Leigh (1976) finds substantial and comparable earnings growth for blacks and whites and suggests that this refutes the dual market hypothesis. On the other hand, Rosenberg (1976) and Carnoy and Rumberger (1980) find that minority workers are more likely to begin their career in the secondary sector and, having started there, are less likely to leave than are whites. These authors argue that this differential mobility supports dual market theory.

Thus authors on both sides confounded lack of mobility with barriers to entry. However, in the extreme no mobility between sectors could be consistent with complete barriers to entry or no barriers at all. If workers always enter the sector they prefer on their first job, there is no need for mobility among sectors. On the other hand, if whiles can 
enter whichever sector they prefer, but blacks must queue for good jobs, blacks will be more likely than whites to move into good jobs.

indeed segmented labor market theory can explain an anomaly that has been largely neglected in the literature on race discrimination. The evidence is fairly strong that within cohorts, wages have risen more rapidly for blacks than for whites (Smith, 1989). On the other hand, Lazear (1979) shows that within a job, wages rise less rapidly for blacks than for whites. This is precisely what would be expected if blacks were more likely to be employed in low-wage jobs with little return to seniority while queuing for good jobs. ${ }^{3}$

By shifting the emphasis from mobility to evidence for queues the question becomes much clearer. Evidence of excess supply in high wage jobs, wage differences unrelated to ability or job quality (and perhaps related to other characteristics not suggested by human

\footnotetext{
${ }^{3}$ While waiting in secondary jobs, blacks experience few wage increases. Since more blacks are in secondary jobs their within job growth rate is smaller than for whites. However, since fewer whites start out in the secondary sector few experience the large wage growth as they move from the secondary to the primary sector. Coneequently overall black wage growth is higher.
} 
capital theory), and that workers in low wage jobs would prefer high wage jobs for which they would qualify, all provide evidence of queues. Since queues imply excess supply to high wage jobs, they also imply some degree of wage rigidity at least in high wage jobs. Thus theories of labor market segmentation require some form of wage rigidity. In contrast with macroeconomic'disequilibrium' models, wages may be somewhat flexible in the short-run. Thus segmentation is consistent with cyclical fluctuations in the short-run as long as wage differentials are maintained in the long run. Exactly the opposite is required for macroeconomic models which must explain temporary deviations from market clearing. Fortunately for labor market segmentation theory, models of long-run rigidity have proven far easier to develop than models of short-run rigidity.

We view the existence of segments with diierent wage-setting mechanisms and queues for high-wage jobs as essential elements of labor market segmentation theory. However, there are several other attributes common to many versions of labor market segmentation theory. The first of these is that the labor market can be usefully modelled as having two major segments - secondary and primary. The latter is often divided into a lower and upper-tier. 
The primary sector consists of high- wage jobs with good working conditions, considerable opportunity for advancement within the firm and substantial rewards for obtaining education and training. Labor relations are generally formalized either by a union contract or in an employment relations handbook. Company policy sharply circumscribes supervisors' authority. Because of the high wages, employees tend to stay on the job for a long time. Because of firms' investment in screening and training, firms tend to hold onto workers. Also, primary firms may insulate themselves from demand swings by contracting out the more volatile portion of demand. 4

The sociological literature on segmentation builds on Averitt's (1968) work on the dual economy. Since tests of the dual economy model often rely on labor market data, it is natural to interpret them as tests of the dual labor market model. It is therefore important to understand the relation between the dual economy and the dual labor market. ${ }^{5}$ The dual economy literature holds that firms (and in some

\footnotetext{
${ }^{4}$ Rebitzer and Taylor (1991) provide a
} formal model of such behavior.

${ }^{5}$ Our presentation follows our recollections of lectures given by Piore to his graduate labor class at M.I.T. in the mid 1970s. 
cases entire industries) can be usefully thought of as being part of either the Core or the Periphery. Core firms are large successful firms with substantial monopoly power. They tend to have a high return on capital, high labor productivii, pay high wages, have high capital/labor ratios and larger, employment, value of output and market share than other firms.

Core firms mainly offer primary employment. Security, janitorial or other very low skilled occupations may be organized as either primary or secondary jobs or may be contracted out. In peripheral firms there is a very small layer of technical, skilled or managerial labor with most employees being unskilled production workers. The canonical example is a small job shop in some durable goods industry. The owner/manager is likely a skilled machinist who owns some older machine tools. He hires unskilled workers at low wages to tend the machines and clean the shop. The typical fast-food franchise also fits the description with an owner/manager overseeing the work of a many unskilled minimum wage employees.

Some industries are dominated by core firms. Others have few such firms. Industries typically viewed as being core include construction, mining, durable goods manufacturing and some nondurable manufacturing, transportation, utilities and FIRE. Agriculture, 
textiles and apparel, retail trade, and most services contain a higher concentration of peripheral firms.

Thus certain industries will tend to employ primary workers disproportionately and others secondary workers. However industry is not a perfect proxy for segment. Neither is occupation since very few occupations are exclusively made up of secondary workers. This caveat must be kept in mind when reviewing research which relies on these proxies. Before turning to a review of this literature, we discuss theories of labor market segmentation.

\section{Labor Market Segmentation and Economic Theory}

As noted above, the notion that technology may create sectors of the labor market with distinctly different characteristics is not particularly controversial. The biggest problem for labor market segmentation theory is explaining why high-wage employers would not lower their wages in the face of excess labor supply. This is related to but slightly simpler than trying to explain unemployment, because labor market segmentation theory need not explain why those who fail to find high wage employment spurn low wage employment. 
Recent theories of involuntary unemployment fall under the rubric of efficiency wage, rent-extraction or rent-sharing theories. verbal descriptions of many, if not all, of these theories date back as far as Adam Smith. However, their recent formalization has generated widespread interest and increased our understanding of their policy and welfare implications. More complete descriptions of these theories and their merits can be found elsewhere (Yellen 1984, Katz 1986, Weiss 1991). We will briefly review their implications for labor market segmentation.

What distinguishes efficiency wage theory from more standard models is that labor productivity depends not only on workers' observable skills and the numbers of different types of workers employed but also on the wage those workers are paid. There are several explanations for why wages might directly affect productivii. In developing countries where the wage is close to the subsistence level, raising wages may improve workers' nutrition and make them more productive (Stiglitz 1976, Bliss and Stern 1978). This model is clearly irrelevant for labor market segmentation in developed economies.

Alternatively higher wages may facilitate worker discipline (Calvo 1979). Raising the wage makes being fired more costly. Shapiro and 
Stiglitz's (1984) presentation of this model has been highly influential. Similarly, raising wages deters quits (Salop 1979, Beaudry 1990). If the firm invests in screening, hiring or training new workers, it may want to pay a premium wage to protect this investment. Both the discipline and the worker-retention efficiency wage models are subject to the criticism that firms can deter shirking or quits more profiibly by having newly hired workers post a bond (Carmichael 1990). Dickens, Katz, Lang and Summers (1989) and Lang and Kahn (1990) suggest several considerations which complicate the bonding solution and suggest why it may not be used in practice. ${ }^{6}$

The adverse-selection efficiency wage model assumes that firms can not observe worker quality perfectly both before and after hiring, but that better workers have better paying alternatives elsewhere

\footnotetext{
${ }^{6}$ Carmichael (1990) has also criticized these models for not being able to predict the correlates of high wages. While this is true of the original models, simple intuitive elaborations eliminate this problem. For example, if in the shirking model firms face a continuum of workers with different unobservable costs of effort and the cost of shirking to the firm is proportional to the cost of the machines people work with then the efficiency wage will depend on the cost of the machines. This could explain the correlation of wages with capital/labor ratios discussed below.
} 
(perhaps in self-employment). Therefore the unobserved qualii of a firm's workforce will be an increasing function of the wage it offers (Weiss 1980). It can be shown that in equilibrium, different firms will pay different wages (Weiss 1990), but it has not yet been determined whether wages and firm characteristics should be related.

Recruiting models emphasize that it is costly for firms to have vacancies. Raising wages reduces the expected length of a vacancy (Weitzman 1989, Lang 1991, Montgomery 1991). It is possible that firms will specialize in making offers at different wages. Where particular firms choose to specialize may be determined by their technology. Unemployment arises because some workers may (randomly) receive no job offers.

Finally, workers' effort and productivity may depend on how fairly they believe they are being treated (Solow 1979, Akerlof 1984). In particular, workers may have expectations about what constitutes a fair wage and may expect to be paid according to that norm. Norms may differ across industries and across firms depending on the history, market structure and technology of the firm or industry.

It has long been acknowledged that unions may raise workers' wages and that the union wage will be related to technology and market structure. It seems reasonable that firms wishing to avoid 
unionization may pay high wages to prevent unionization. Even without a formal union, worker collective action or the threat of worker collective action may raise wages. This is the theme of the rentextraction/collective action/insider-outsider models (Dickens 1986, Lindbeck and Snower 1986).

In the expense preference or rent-sharing model (Heywood 1990), managers find their jobs are made easier by paying higher wages. Stockholders are unable to audit the true needs of the firm perfectly. Therefore managers hire over-qualified workers and pay them high wages to make their own jobs more pleasant.

Our review of the empirical literature will demonstrate that these theories do not explain the empirical evidence equally well. However, labor market segmentation theory has come a long way in the last decade. It is no longer a set of observations in search of a formal theory. Instead its partisans have the problem of sorting through a host of promising explanations.

The Evidence Part I: Inter-Employer Wage Differences

In this section we consider evidence that there are large differences among employers in the wages paid apparently similar workers. This finding is obviously consistent with labor market 
segmentation but can be made consistent with human capital theory. We argue that examining additional predictions of the labor market segmentation and human capital models and considering the dynamic of their interaction strongly suggests that the market segmentation view should be preferred.

Economists have known for a long time that large wage differences may exist for workers doing similar work at different firms within the same city. Attention to these differences, their distribution across industries, similarity across occupations, and their persistence over time led a previous generation of labor economists and industrial relations specialists to conclude that worker bargaining power determined wages which were then greater than the opportunity cost of workers' time. However, that work left much to be desired. Since micro-data were unavailable at the time the studies were done, they relied on aggregate data allowing few controls for worker quality, geography or differences in job characteristics.

The work was sufficiently flawed that labor economists trained in the 60 s and 70 s felt free to ignore it despite a brief revival of labor market segmentation theory in the early 70 s. New evidence of interindustry and inter-employer wage differentials generated using micro data in the early 1970 s was easily dismissed by the critics of labor 
market segmentation theory as being due to unobserved compensating differences (Cain 1976). Others suggested that such differences might be due to transitory demand for industry specific skills so that such industry differences would disappear over time.

Spurred by the theoretical developments described in the last section, in the last decade several papers have revived the study of industry and employer wage differentials. By using micro-data they go beyond the work of the 40 s and 50 s. By responding directly to the critics of labor market segmentation theory they go beyond the work of the 70s. The best known papers on inter-industry wage differences (Dickens and Katz 1987a\&b, Krueger'and Summers 1987 \& 1988, Katz and Summers 1989) and intra-industry wagevariation (Groshen $1987,1988 a \& b)$ overlap considerably. This presentation follows Dickens and Katz's (1987b) analysis of the 1983 Current Population Survey except where more recent evidence is available,

Among 1 -digit occupations, the standard deviation of log Wages' across 3-digit SIC industrles ranges from .13 (clerical workers)

\footnotetext{
'Standard deviations of the natural log of wagee can be roughly interpreted as percentages.
} 
to .37 (sales workers). Controlling for a wide range of worker attributes, state of residence and residence in an SMSA, has little effect on the dispersion of clerical workers' wages. However, it reduces the standard deviation of industry effects to .29 for sales workers. Thus controlling for nearly everything available in the CPS leaves substantial unexplained inter-industry variation in wages. Even for clerical workers, an industry two standard deviations above the average would pay over fifty percent more than one two standard deviations below the average.

Not only are these differences large, they are persistent across time. Dickens and Katz (1986b) review a number of studies using aggregate data which show remarkable persistence in the inter-industry wage structure going back to the late 1800s. Helwege (1987) uses census data going back to 1940 and controls for individual characteristics and geographic location. She finds that the correlation of the inter-industry wage structure across time is even stronger when these controls are added.

In addition to being correlated across time, inter-industry wage differences are also correlated across space. Many studies have shown that average industry wages are correlated across countries (see Dickens and Katz 1987b). Lang, Marquez and Romaguera (1989) found that Venezuelan 
wage differentials were more highly correlated with U.S. and Chilean differentials after human capital controls. Lucifora (1991) replicates many of the results of Dickens and Katz (1987b) using Italian data Slichter (1950) found that the average wages of skilled and unskilled workers were highly correlated across industries. However, he could not control for geography and worker characteristics. Also, the categories of skilled and unskilled are relative and may. not be consistent across industries. Dickens and Katz (1986b) estimate the correlation of industry wages for different one digit census occupations controlling for the same wide range of variables described above and find a median correlation of .79 . Widely different occupations all show the same effect of being in a high wage industry. For example, clerical workers and transportation equipment operatives have a correlation exactly equal to the median.

Given the similarity of industry wage patterns in so many dimensions, it becomes interesting to examine the correlates of industry wage differentials. Our inferences about the source of differentials might differ if they were associated with average worker quality and research and development rather than industry concentration, capital/labor ratios and profitability. 
In fact, industry wage differentials are associated with all these and other factors. Dickens and Katz (1987a) show that there are large simple correlations between measures of industry wage surplus and the industry quit rate, labor productivity, average years of education, average job tenure, average age, percent of the workforce which is female, the layoff rate, the injury rate, hours worked per week, the ratio of the dollar value of total compensation to wages and salary, union coverage, firm size, concentration ratios, $R \& D$ expenditures, capital labor ratios, percent production workers, profits as a percent of sales, profits per worker, and the rate of return on fixed capital. This is a long list which supports many interpretations.

As dual labor market theory and dual economy theory suggest, many job characteristics are highly correlated. Consequently, attempts to establish which relations are most important have been largely fruitless. The literature on the relation between industry wages and industry characteristics reveals little consistency (Dickens and Katz 1987a). Different data sets and specifications yield widely different results as to which variables are primary in explaining the diierences. When Dickens and Katz perform their own analysis they find the same inconsistency. Only average education and profitability are consistently related to industry wages in all specifications. The high level of 
collinearity in the data makes it impossible to sort out the individual contribution of specific variables. ${ }^{8}$

Going below inter-industry differences, Groshen (1987) finds large differences in wages across employers within industries which explain a substantial amount of individual wage variation. Her (1988b) paper demonstrates that these differences are quite persistent. 9 Groshen (1988a) reviews nearly two dozen studies finding similar results. Among these, Hodson (1988) matched individual and firm data and was able to control for many individual characteristics, while Evans (1989) and Conant (1988) found that standardized tests of clerical skills do not explain the inter-employer variation in clerical wages.

Could these inter-industry and inter-employer diierentials arise in markets which clear? Broadly, there are three possible market clearing-explanations for inter-employer wage differences - transitory

\footnotetext{
${ }^{8}$ of course this is exactly the sort of "reduction in the dimensionality of job characteristics" that labor market segmentation theory requires. We discuss this evidence at greater length below.

'Leonard (1989) shows that this is not true of the electronics industry in California's Silicon Valley. In this new industry firm relative wages are quite volatile.
} 
returns to industry specific skills, compensating differences for working conditions, or returns to unmeasured ability.

The first of these interpretations can be easily ruled out by the evidence showing strong correlations of industry and employer wage patterns over several decades. The second is not as easily dismissed, The similarity of industry wage patterns across countries suggests a technological explanation which would fit with compensating differences. However, a number of other aspects call this explanation into question. First, several studies have controlled for a wide range of job characteristics (see for example Krueger and Summers 1988). These studies find little or no effect on industry wage differences. If anything, industry wage differences are exacerbated by consideration of job characteristics. This would be consistent with industry wage differences giving workers larger incomes and job quality being a normal good. Second, since wage differentials are highly correlated across occupations, the compensating differentials explanation requires that job characteristics also be highly correlated. It is difficult to claim that industry-specific job characteristics are shared by secretaries and truck drivers.

The possibility that workers in high wage industries receive a return on some unobservable skill is subject to the problem of 
explaining the similar wage differentials across occupations. Why would an industry that required highly-skilled truck drivers also require highly-skilled secretaries? Recall also that previous studies found that standardized tests of clerical ability can not explain inter-employer differences in clerical wages (Evans (1960) and Conant (1963)). There are additional problems this explanation must address. Suppose that high wage industries are industries which disproportionately employ high quality workers. If this ability is useful in any industry, then when workers change industry, their wages should not change significantly. Several studies have examined this question. Except for Murphy and Topel (1987), all find that industry changers'wages increase or decrease by nearly the full amount of the difference between the average wages of the two industries (Krueger and Summers 1988, Blackburn and Neumark 1988, Gibbons and Katz 1989). Murphy and Topel find that industry switchers receive only about thirty percent of the difference between industries. However, their study has been replicated on a different data set by Gibbons and Katz (1989) who find that changers receive seventy-five percent of the average industry difference. These results rule out a universally valued skill as the explanation for inter-industry differences. However, it is possible that inter-industry differences reflect a return to skills which are more valued 
in the high wage industries. Indeed, it is hard to explain why high skill workers would be concentrated in high wage industries if their skills were not valued more highly there although one might still expect more skill transferability than the results discussed above suggest. Again, the high correlation of the wage patterns across occupations limits the types of industry specific skills that can be considered. The skill (or skills) must be valuable to both truck drivers and managers in the high wage industry, but not to those in low wage industries. It is not obvious what these skills would be, but perhaps the question can be finessed by assuming significant complementarities among different types of workers in a firm. Further, such job matching would be consistent with low quit rates in high wage jobs. However, the existence of sorting does not mean that wages are market clearing. An employer forced to pay high wages by a union would at least partially offset the effect by using the higher wage to hire more able workers.

How much of the observed inter-industry differences can be explained by unobserved ability? Murphy and Topel (1990) argue that if there is sorting on observed ability there should be at least as much sorting on unobserved ability since so much is unobserved to the econometrician. It is plausible that much of what is not observed by the econometrician is also not observed by the employer so that the 
Murphy/Topel assumption is not self-evident. Nevertheless, we will accept it for the purpose of discussion. They then examine the extent of sorting on observed ability and conclude that about 30 percent of the wage premium can be explained by matching and unobserved ability if marital status is treated as a measure of ability. A much smaller fraction is explained when sorting on education is examined. ${ }^{10} \mathrm{~T} \mathrm{~h}$ e argument that marital status is a better measure of ability than education is rather strange. Marital status has not traditionally been treated as a human capital variable. Moreover, marital status may be determined by job status rather than vice versa People may wait until they are established in a good paying job before they decide to marry and have a family.

One piece of evidence suggests that inter-industry wage differences may be due, at least in part, to unobserved ability. Kletzer (1989) and Gibbons and Katz (1989) find that the wage differential in one's previous industry helps predict the wage on a new job after job

\footnotetext{
${ }^{10}$ They conclude that all of the inter-industry difference can be explained by the combination of sorting and unobserved ability. This is because by their estimates only about thirty percent of inter-industry differences can not be attributed to common unobserved ability (see the discuraion of this evidence above).
} 
displacement. That finding is predicted by the unobserved ability explanation and might not be anticipated from other perspectives. However, if one assumes that networks of connections or employer discrimination on the basis of non-pecuniary characteristics are important in access to good paying jobs as some have argued (for example Bowles and Gintis 1976) then this result is understandable.

In sum, the best remaining modification of human capital theory is one in which there are differential returns to unobserved skill across industries. It is consistent with or plausibly modifiable to be consistent with many of the facts about inter-employer differences. It has generated one new finding but faces two major anomalies -the inter-occupation correlations and the inability to explain the lack of sorting on the basis of observable human capital characteristics. Further, this version of human capital was reached after a series of modifications. Until recently, human capital theory ignored the possibility of inter-industry wage differentials or dismissed them as being due to transitory skill premiums or compensating differences received 'by some workers in the industry. When documentation of these wage differentials became the focus of the revived labor market segmentation research program of the 1980s, and the cross-occupation correlations were demonstrated, researchers first searched for a 
common source of compensating wage differentials (employment fluctuations) (Topel and Murphy (1987)). When this failed to explain the evidence they then tried to explain the differentials by the existence of unobserved abilities which were equally useful in all industries. The next step involved differentially-valued unobserved ability and a job mobility model based on life-cycle considerations. Finally, we have reached the present modified human capital model. It remains to be seen whether the latest human capital model will prove to be a fruiiul and progressive approach to industry wage differentials.

On the other hand, the labor market segmentation approach, while also suffering setbacks, has been much more progressive. If wage differences represent worker rents, we would expect differences in quit rates and application rates across industries with different wages." Several studies have found a negative association between quit rates and wage premiums. Holtzer, Katz and Krueger (forthcoming) find that application rates are higher in high wage industries. While the market-clearing models can be made consistent with this result and the

\footnotetext{
${ }^{11}$ It is possible to create compensating difference models with both these properties. Our argument is not that these findings are incompatible with such models, only that one would not expect them a priori.
} 
differentially-valued ability model predicts it, it was the labor market segmentation models which generated the initial prediction.

The labor market segmentation model also predicts that individuals getting high-wage jobs should consider themselves lucky. The Boston working class men interviewed by Howard Wial (1988) clearly distinguished between good and bad jobs. Further, most did not think that the good jobs went to the more able. Even those who held high paying jobs generally attributed their having them to luck or to connections. To get a good job, even a non-union one, workers felt they needed someone who would let them know when jobs were available so that would know when to apply. A friend or relative might also intercede with the person making the employment decision. Otherwise one needed to be phenomenally lucky to show up at the right time when jobs were being filled.

Similarly, the labor market segmentation model predicts that employers will give reasons other than ability for wage differentials. Fred Foulkes's (1980) managers did not see themselves as getting what they paid for in worker ability. He interviewed personnel directors at several large non-union U.S. firms and concluded that paying enough to avoid unionization was the major consideration in determining pay. These managers relied heavily on industry wage surveys, even for 
workers for whom local wage surveys would have given more relevant information from a competitive labor market perspective.

While labor market segmentation theory is successful in making these predictions, without an explanation of why differentials arise the power of the theory would be limited. The last decade has seen the development of a number of competing (efficiency wage) models which we discussed above. Some of these models do not fare much better than the market-clearing ones. The simple labor discipline and quits models have as much trouble explaining the high correlation of interemployer wage differences across different occupations as a marketclearing model. The adverse selection model and the employer search model are somewhat easier to fit with these findings. Wage norm models and rent-sharing or rent-extraction models predict these correlations. In fact, it was to test such models that Dickens and Katz undertook their study. But, the wage norm theory has particular difficulty explaining the cross-national evidence. Why would the same wage norms prevail in such distinct countries as the Soviet Union, Germany, Chile, Korea, Japan and the U.S.? The rent-sharing and rentextraction models are also challenged by this evidence. Why should the pattern of rent-sharing be so similar in such different economic systems? To believe that rent-extraction is the explanation for the inter- 
industry differences, one must believe that workers have substantial power even in very repressive systems.

This may not be that far-fetched. Marshall Goldman (1983) reports on a number of large organized labor actions in the Soviet Union aimed at securing higher wages or better working conditions. These are overt actions. Doubtless, covert actions are even more plentiful in repressive societies. Mars (Cheats at Work 1982) and Mathewson (Restriction of Output Among Unorganized Workers, 1989) describe numerous examples of such behavior in the United States.

Thus the labor market segmentation program has been very progressive. Plausible theories have been put forward and evidence on inter-industry wage differences has provided considerable support for those theories. Very little back-tracking has been necessary to explain the facts. Further evidence of the progressivity of the program follows.

Evidence Part II: Tests for Labor Market Segmentation

Many researchers (Gordon 1971, Buchele 1976a\&b, Oster 1979) have chosen to test labor market segmentation theory by factoranalyzing data on industries, occupations or individuals. These studies find that the majority of the systematic variance can be explained by one or two factors, and nearly all by four or five. Further, in all the 
studies one of the two factors which 'explain' the most standardized variation fiis with the descriptive literature on, dual labor markets, Job and worker characteristics associated with the primary sector load positively on the factor while characteristics associated with the secondary sector load negatively. Thus while the dual market distinction may not be the only relevant distinction, it is clearly an important one. There does seem to be a high degree of association between different job and worker characteristics so that the dimensionality of these characteristics can be usefully reduced as labor market segmentation theory suggests.

Two other approaches are to look for differences in the wage determination mechanism between different labor market segments and to look for barriers to mobility between the sectors. Most studies have used a priori classification systems, often derived from factor analysis of industry or occupation data Studies taking this approach have usually been supportive of the view that there are different wage determination mechanisms in the diierent sectors. Examples of such studies include Osterman (1975), Carnoy and Rumberger (1980), Buchele (1976a,b), Rosenberg (1976), Wright (1979), Beck, Horan and Tolbert (1978), Heckman and Sedlacek (1985), and I-leckman and Hotz 
(1 986). ${ }^{12}$ However, Zucker and Rosenstein (1981), Bibb and Form (1977), Hodson (1977), and Tolbert, Horan and Beck (1980) find little support for the dual market typology, and even the supportive studies are not free of anomalies.

Further, all these studies, except the two by Heckman and his co-authors, fail to account for the endogeneity of an individual's labor market segment. This is Cain's (1976) main criticism of this work. Figure 1 illustrates the problem. If we arbitrarily divide a single market into high and low wage sectors, with most workers in the high wage sector, the estimated equations will tend to fit the dual market typology. Returns to education (or other measures of ability) will be lower in the low wage 'secondary' sector and that wage equation will lie generally below the 'primary' sector equation. One solution is to use a priori classification systems but to correct for the sample selectivity bias in estimating separate equations. This is the approach taken by Heckman and Sedlacek and Heckman and Hotz. However, dual market theory

${ }^{12}$ Most of these studies use specially created a priori classification systems based on industry and/or occupation codes. Heckman at Sedlacek contrast the wage determination mechanism in manufacturing vs. the rest of the economy and Heckman and Hotz divide workers into primary and secondary sectors on the basis of their earnings. 
suggests that it is difficult to determine a priori who is in which sector. Recall from our discussion above that even within the same firm (let alone industry), there may be both primary and secondaryworkers. Further, since some job titles such as operative are broad and many 'secondary' occupations are treated like lower-tier primary jobs in some firms, occupational classification systems are suspect. Thus it is appropriate to treat sector as unknown.

In a series of papers we have implemented a technique which allows us to estimate the wage equations for unobserved sectors simply by postulating the number of sectors and the determinants of sector attachment. Dickens and Lang (1985a) is the first paper to present this approach. We turn to a description of that procedure now.

Consider how we might proceed if people's earnings potential could be summarized by a single observable trait--for example, education--and an unobserved trait which was uncorrelated with education. In that case we could plot a scatter diagram of log wages and education. The standard view of the labor market holds that such a scatter diagram should resemble Figure 1. From dual market theory We would expect a scatter diagram similar to Figure 2. A straightforward test of the theories would therefore entail plotting the 
Scatter diagram and assessing whether it corresponds to either the human capital model or the dual market model.

Two problems complicate such an approach. First, wages are determined by many observable characteristics other than education. To control for all variables simultaneously, we would have to plot a scatter diagram for each subgroup in the sample. As the number of other variables increased, the number of observations on each diagram would decrease considerably. With a reasonable number of controls, the number of diagrams and the sparseness of observations would certainly make it impossible to discern any pattern. Second, even if we were able to plot all the scatter diagrams, we would still lack a formal mechanism for testing the hypotheses. Each researcher could decide for him/herself whether the diagrams correspond more nearly to the predictions of human capital or dual market theory. These problems can be resolved by the use of the formal methods described in the following paragraphs..

The question of whether a plot looks more like Figure 1 or 2 can be rephrased: do two wage equations fit the data significantly better than one, and do the best-fitting equations fii the predictions of the dual market hypothesis? We can imagine fifing first one, and then two lines by hand to Figure 2. To compare the explanatory Power we 
might, for example, compute the distance from each point to the closest fine. The reduction in the sum of squares going from one line to two would be much larger for Figure 2 than for Figure 1.

Of course, two equations having more explanatory power than one is not, by itself, a test of the dual market hypothesis. For example, two equations might have significantly more explanatory power than one for a scatter diagram such as Figure 3. However, there is no identifiable secondary market. Thus, in addition to requiring two equations to have significantly more explanatory power than one, we also require the best-fiiing lines to have characteristics consistent with the dual market hypothesis. To correspond to the predictions of dual market theory, one wage equation should be upward sloping in schooling and experience. The other equation should be nearly flat with respect to human capital variables and below the other at most points. Since we are dealing with a sample of adult males, we also expect that there will be fewer observations associated with the lowwage line.

Formally, we may fit two wage equations using maximum likelihood techniques. Since we do not know a priori with which wage equation to compare an individual, we estimate a switching model with 
unknown regimes. To do this we must specify two wage equations and a third equation that predicts sector attachment, and estimate all three equations simultaneously. Since the single-equation model is nested in the switching model, we may test the hypothesis that the twoequation model fiis significantly better than the single-equation model by comparing the log-likelihood values for the two models. If we reject the single-equation hypothesis, we may examine the coefficients of the two wage equations to see if they fit the dual market hypothesis.

The results of our 1985a study were remarkably consistent with the dual market typology. Two wage equations fit the data considerably better than one with a chi-squared statistic of 177. A conservatively constructed $1 \%$ critical value is $29.14 .^{13}$ Further, the estimated parameters of the two wage equations and the switching equation fii perfectly with the predictions of the dual market typology. One equation shows large and significant returns to education and

${ }^{13}$ since some of the parameters of the dual market model are not identified when the single equation model is imposed as a constraint the distribution of the test statistic is unknown. However the Monte Carlo tests of Goldfeld and Quandt (1976) suggest that setting the degreee of freedom equal to the number of constraints plus the number of unidentified parameters yields a conservative test using the chisquared distribution. 
experience. The other shows absolutely no returns. The switching equation showed, consistent with the dual market typology, that those who lived in cities, were married and were white were more likely to be found in the primary sector.

Given the remarkable consistency of these findings with the dual market typology it is interesting to ask what the problem was with earlier studies which used A priorisclassifiaation §ystents. e d above, it seems likely that all these systems misclassify many workers. Prima facie evidence of this is presented by Zucker and Rosenstein (1981). Correlations among classification schemes that divide industries into core and periphery sectors are relatively weak, ranging from $57 \%$ to $85 \%$ agreement for the four taxonomies they studied. The degree of disagreement is striking when one considers that if each study had assigned people to the sectors randomly but in the same proportions as in the actual studies, the level of agreement would have ranged from $40 \%$ to $50 \%$. Obviously systems based solely on industry will disagree considerably with those based solely on occupation since many occupations are common to many if not all industries. Do any of these systems come close to correctly identifying the sectors?

To answer this question we need to apply the switching equation technique to a very large data set so that we can accurately 
estimate the fraction of primary and secondary sector workers in the detailed industries and occupations used in the a priori classification systems.

The data used for this study are drawn from the 1963 Current Population Survey. All male heads-of-households between 20 and 65 years of age who were employed, reported that they normally worked more than twenty hours a week, earned more than the minimum wage, and for whom data on wages 14 and all independent variables were available were included in the sample. We limited ourselves to individuals who were in their fourth or eighth interview month. Screening on this basis left us with 46,411 observations. The sample was restricted to men because of the substantially different nature of many women's jobs and the difficulty of fitting them into the dual market typology. In particular, pink collar jobs have many characteristics of both primary and secondary jobs. The other restrictions ensure that if a secondary sector is identified by the analysis, it consists of more than part-time earners or those with transient labor market attachment.

\footnotetext{
${ }^{14}$ For salaried workers, wage8 are computed by dividing weekly earned income by normal hours of work.
} 
We begin by estimating our original model with the modifications that experience squared is included in the wage equations and that experience and its square are included in the switching equation. ${ }^{15}$ As can be seen in Table 1, this does not significantly alter the results. The first column of the table gives OLS estimates while the second through fourth columns give the primary sector, secondary sector and switching equation estimates. As in our previous work, the primary sector equation is similar to that obtained using OLS estimation. The returns to education and experience are somewhat higher in the primary sector than in the OLS equation and the black-white wage differential somewhat lower. In contrast to our previous work, we can reject the hypothesis of no black-white wage differential in the primary sector. In the secondary sector there is no return to schooling and a perverse effect of experience. There are also somewhat surprisingly large effects of living in an SMSA and never having been married on secondary sector wages. The chi-squared statistic for the test of the hypothesis that only one wage equation is

\footnotetext{
${ }^{15}$ Experience is measured as Age (Years of schooling +5 )
} 
needed to describe the data is 2,369 . The hypothesis can be rejected at any conventional level. ${ }^{16}$

These results continue to be strongly supportive of the dual market view, Therefore we now turn to misclassification error in previous studies. Our estimation technique entails calculating a probabilii of being in each sector for each worker. These estimates are in some sense ex ante. Having estimated the wage equations, we can recompute the probability that each individual is attached to the primary sector. The two probabilities have very different interpretations. The probability calculated in the course of the estimation technique is the ex ante probability that the worker will end up in the primary or secondary sector. However, ex post, each worker is either in the primary sector with probability one or in the secondary sector with probability one. The ex post probability we calculate is therefore a measure of our ignorance - how certain we are that this individual is in the primary sector. Thus, if we estimate that an individual has a $99 \%$ probability of being in the primary sector, we are reasonably certain that he is in the primary sector. If we estimate that he has a $59 \%$ probability of being in the primary sector, we have no information about sector of

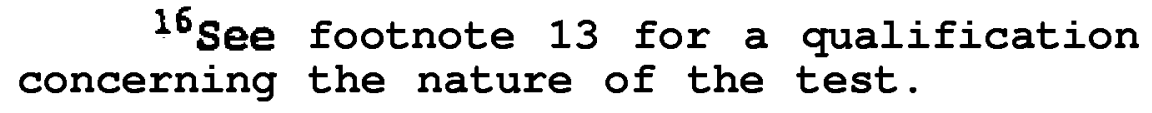


attachment. Therefore, to describe the composition of an industry or occupation we calculate the proportions of workers in that industry or occupation whom we can accurately classify as being in the primary sector or as being in the secondary sector and the proportion for whom sector of employment cannot be accurately ascertained.

Tables 2 and 3 show the breakdown of sector attachment for several industries and occupations. The three columns next to each category show the percent of people in that category who had a $030 \%$ probability of being in the secondary sector (secondary workers), a 30$70 \%$ probability (?s) and $70-100 \%$ probability (primary workers). The results are substantially in accord with descriptive work on the dual market. Agricultural workers, retail sales workers, and service workers are more likely to be associated with the secondary market. Most manufacturing workers are very likely to be in the primary sector, but textile and apparel workers are not Also, more secondary workers can be found among operatives in manufacturing than among the skilled crafts. One notable attribute of these tables suggests why past studies have often produced anomalous and inconsistent results. None of the industries or occupations examined is identifiable as being entirely secondary. It seems that even in those industries or occupations which are substantially secondary, there are many people who are probably 
primary workers. This finding is not an artifact of our choice of industries or occupations for this table. It was true of all occupations and industries for which there were enough people in our sample to be confident of the composition estimates. With over 48,000 people this was nearly all two digit categories and very many three digit categories.

A large number of classification schemes have been used in previous research. The large degree of misclassification which is inherent in a priori schemes suggests that one reason for the inconsistency of results across studies may be varying degrees of inaccuracy. To cast light on this possibilii, we review four industrial classification schemes (Beck, Horan and Tolbert, 1978; Tolbert, Horan and Beck, 1980; Bibb and Form, 1977; Hodson, 1977) and one occupational classification scheme (Osterman, 1975). We chose these studies because Zucker and Rosenstein (1981) have reanalyzed the industrial schemes, permitting a direct comparison of their results and because the analysis in Osterman is comparable to that used by Zucker and Rosenstein.

Zucker and Rosenstein compare the classification schemes first by examining the average characteristics of workers in each sector. Of the seventeen characteristics examined, Beck, Horan and Tolbert's classification system produced the anticipated differences in means for 
twelve, Tolbert, Horan and Beck's for nine, Bibb and Form's for seven and Hodson's for six. In addition, Zucker and Rosenstein estimated separate earnings equations for each sector for the four classification schemes. Beck, Horan and Tolbert's (1978) system was the only one which produced significantly diierent results in the two sectors. Thus among the industrial classification schemes, Beck, Horan and Tolbert's performed somewhat better than the others, followed by Tolbert, Horan and Beck, Bibb and Form and Hodson.

Studies which have used occupational classifications have generally been more supportive of dual market theory (Rosenberg, 1976; Osterman, 1975). In particular, Osterman estimates sharply differing wage equations for the primary and secondary sectors, and the differences correspond to the predictions of dual labor market theory.

Table 4 presents our estimates of the true distribution of workers in each of the five studies' 'sectors.' Our results suggest that all four schemes are broadly consistent with the data. Sectors classified as periphery or secondary contain a higher fraction of secondary workers and fewer primary workers. However, all four schemes also misspecify many workers. Thus it is not surprising that 
the evidence generated by using these classification systems is so mixed.

Osterman's occupationally based classification scheme does a much better job than the industrial schemes of dividing workers between sectors although there is substantial misspecification. It nevertheless appears that his results are strongly supportive of the dual labor market hypothesis because his classification scheme is more accurate than those used by other researchers, Further, the two schemes used by Beck, Horan and Tolbert, which performed marginally better in Zucker and Rosenstein's comparison, perform slightly better than the other two systems here. Both have fewer primary workers misclassified as being in the periphery, and more secondary workers who are correctly classified.

Is it surprising that two equations fit the wage distribution significantly better than one? Several critics of our approach have suggested that it is not. They argue that the standard OLS wage equation is too simple to be taken too seriously. In particular, the error term is known to be heteroskedastic. These critics suggest that if we tested our dual market specification against a more general Single equation model with heteroskedastic errors, we would no longer reject the single market model. 
We have now done this (Dickens and Lang 1987). In that paper we estimated a 22 parameter single equation model (our dual labor market model had 21 parameters). Eleven of the parameters were coefficients of the wage equation including terms for a constant, dummies for residing in an SMSA, never having been married, and race and measures of years of schooling, years of schooling squared, years of labor market experience, experience squared, and interactions between schooling and experience, race and schooling, and race and schooling squared. The same eleven terms were also allowed to describe the heteroskedasticty - a very general model. Several other specffications were tried. This fii best. The predicted distribution based on the general heteroskedastic single equation model was then compared with the true wage distribution. The model is rejected at any conventional level of significance. Even this very general model fails to track the true distribution of wages. It predicts fewer low wage workers and many more middle wage workers than are observed. It also tracks the upper tail poorly.

How well does the dual market model do in the same test? With one less degree of freedom, the dual market model fits the empirical distribution sufficiently well that one can not reject it at the $5 \%$ level. It is possible to reject the model at the $10 \%$ level, but Only 
because the dual market model is unable to predict the bunching of wages at values of $\$ 7.50$ and $\$ 10.00$ an hour. Other than that, the theoretical distribution implied by the dual market model conforms to the empirical distribution quite closely.

All of the studies described above are restricted to studying the labor market experience of men. A failing of the dual market approach has been our inability to extend it to women. We anticipated this, and consequently our early work excluded women. The 'pink collar" sector fits neither the description of the primary or the secondary sector. Like the secondary sector such jobs are typically 'dead end.' Therefore one would expect little return to experience. On the other hand, such jobs tend to be concentrated in large primary firms, and education may help women obtain better jobs within the pink collar sector. This is close to what Friedberg, Lang and Dickens (1988) find. Nearly all women are located in a women's sector with little return to potential experience but with substantial returns to education.

So what does it mean if two equations fit better than one? The existence of two sectors with different wage-setting mechanisms is fundamental to dual market theory, but it is not incompatible with human capital theory. Neoclassical economics tends to emphasize models which are continuous and therefore tractable in calculus. 
However, if the technology were sharply discontinuous in the way suggested by Piore (1980b), no fundamental assumptions of mainstream economics would be violated. In this case, individuals would choose the sector of employment that maximized the expected present value of their lifetime utilii.

The second tenet of dual market theory, that primary sector jobs are rationed, is less compatible with human capital theory. Dual market theory maintains that individuals cannot always choose the sector which they prefer. Some workers who would prefer to be employed in the primary sector cannot find jobs there. On the face this seems likely. Who would prefer to work in the secondary sector when his wages would be substantially lower than in the primary sector throughout his work-life? For example, given the results in table 1, an average white maried city-dweller with a high school education would start out earning $\$ 4.61$ an hour more in the primary sector and continue to earn at least that much more throughout his career. Even an average unmarried non-white who lived outside a SMSA -for whom the primary/secondary difference is minimized --would earn more in the primary sector for his entire career if he had more than a high school education. The same person with a ninth grade education would be earning more in the primary sector in less than five years. A similar 
person living in an SMSA would always be paid more in the primary sector.

Some people might prefer the nonwage characteristics of the secondary market. However, descriptions of the secondary sector are unanimous in maintaining that the nonpecuniary aspects of secondary employment are inferior to those in primary employment making this unlikely. Nonetheless, secondary employers may be less concerned with lateness and absenteeism and the work pace may be slower in secondary jobs. Therefore it is worthwhile to consider another test.

To implement this test we need to postulate a mechanism for allocating workers between the sectors in the absence of rationing. In our 1985a paper we assumed that experience in one sector raises wages in the sector more than it raises wages in the other sector. We also assumed that workers will behave so as to maximize utility over their lifetime. Utility was assumed to be increasing with the net present value (NPV) of lifetime income. Assuming further that workers are perfectly informed about job characteristics and that preferences about the, nonpecuniary aspects of jobs do not change over their lifetime, workers will choose one sector and stay there permanently.

If the nonpecuniary characteristics of the two sectors were similar, workers would pick the sector that yields the highest lifetime 
income. To allow for differences in how workers perceive the nonpecuniary value of secondary employment, we assume that workers will choose primary sector employment if the log of the NPV of their income stream in the primary employment exceeds the log of the NPV of secondary employment by more than an amount $\mathrm{C}$--the additive inverse of the compensating diierential for secondary employment. We may write the probability that a worker is employed in the primary sector (denoted $P$ ) as

$$
P=\operatorname{Pr}\left\{\ln \left(N P V_{p}\right) \cdot \ln \left(N P V_{s}\right)>C\right\}
$$

where the subscripts $p$ and $s$ denote primary and secondary. To model the NPV in the two sectors, we write the two wage equations:

$$
\ln \left(W_{p}\right)=X B_{p}+Y a_{p}+\theta_{p}
$$

$$
\ln \left(W_{s}\right)=X B_{s}+Y_{s}+\theta_{s}
$$

where $X$ is a vector of individual characteristics, $Y$ Is years of job experience, $\boldsymbol{W}_{\boldsymbol{p}}$ is the wage received in the primary sector, $\boldsymbol{\theta}_{\boldsymbol{p}}$ is a 
normally distributed error representing unobserved characteristics affecting the primary sector wage, and $B_{p}$ and $a_{p}$ are parameters. The terms $W_{\underline{S}^{\prime}} e_{S_{-}^{\prime}} B_{\underline{S}^{\prime}}$ and $a_{s}$ are similarly defined for the secondary sector. Approximating the length of the individual's working life by infinity, and using (2) and (3), equation (1) becomes

$$
P=\operatorname{Pr}\left\{X\left(B_{\underline{p}}-B_{\underline{\underline{g}}}\right)+e_{\underline{\underline{p}}}-e_{\underline{\underline{s}}}+C^{\prime}>0\right\},
$$

where

$$
C^{\prime}=\ln \left(\left(d \cdot a_{g}\right) /\left(d \cdot a_{p}\right)\right) \cdot C,
$$

and $d$ is the discount rate.

If we assume that $C^{\prime}$ is equal to a constant $\left(C^{\prime}\right)$ plus a normally distributed error term which is independent of $X$ and $d$ (i.e., people's preferences with respect to the nonpecuniary aspects of employment and their discount rates do not vary with observable characteristics $(X)$ ), we may test the hypothesis that people choose their sector of employment to maximize their utility. We do this by estimating an 
equation to determine sector membership and testing the hypothesis that the coefficients on the $X$ 's are equal to $B_{\underline{p}} \cdot B_{\underline{s^{\prime}}}$ or that the $B_{w}$ 's in

$$
X\left(B_{\underline{p}}-B_{\underline{s}}+B_{\underline{w}}\right)+C^{\prime}+\theta_{\underline{p}}-e_{\underline{s}}+e_{\underline{w}}
$$

are equal to zero.

Alternatively, we might assume that experience is equally valuable in both sectors independent of the sector in which the person worked. In that case people with free choice will, at each point in time, choose the sector which maximizes their utilii. In that case equation (6) becomes

$$
X\left(B_{p}-B_{\underline{s}}+B_{\underline{w}}\right)+C+Y\left(a_{\underline{p}}-a_{\underline{s}}+a_{\underline{w}}\right)+\theta_{p}-\theta_{s}+\theta_{w}
$$

where $Y$ may be either experience or a vector of experience and experience squared, and the a's are conformable vectors of parameters.

It may be reasonable to assume that preferences for the nonpecuniary aspects of primary or secondary employment are related to some observed worker characteristics. If so, at least some of the 
$B_{\underline{w}}$ 's would be different from zero even if workers can choose the sector in which they are employed. In this case we may be able to find some X's that should not be related to tastes, or to suggest the direction of their effects. We propose specific tests of this type below.

An intuitive explanation of this approach uses the example of race. Suppose that the lines fitting the scatter diagram in Figure 3 were the same for blacks and whites. Suppose further that the distribution of education was the same for the two groups, but that a higher proportion of blacks than of whites were scattered around the lower line. Under these circumstances, we would conclude that either blacks are less averse to secondary employment than are whites, or that blacks face discrimination in obtaining primary jobs. Supplementary evidence would support the latter explanation.

We have no strong expectations regarding the effect of living in an SMSA, experience, or never having been married on tastes for secondary sector employment. However, there is no reason to believe that blacks will be less averse than whites to the working conditions in the secondary sector. Indeed, auxiliary evidence discussed in Dickens and Lang (1985a) suggests the opposite may be true. Also we expect more educated workers will be indiierent or more averse to secondary 
employment than other workers. Therefore we limit ourselves to testing the relation between the wage and the switching coefficients for education and race. In our 1985a paper we test this hypothesis excluding experience from the switching equation and reject it at the .01 level. Here we include experience and experience squared in switching equation to allow for mobility between the sectors. Again we reject the hypothesis of free choice between the sectors at the .01 level."

A potential problem with our test for queuing is that we include union members in our sample. Not surprisingly nearly all are found in primary sector jobs (see Dickens and Lang 1985b). One might argue that it is no surprise that there are queues for union jobs and that may be all we are seeing. To answer this objection we estimated a three equation switching model with one known regime (union) and two unknown regimes (non-union primary and secondary) (Dickens and Lang 1988 and 1986). We found that even with the union sector treated separately there were distinct non-union primary and secondary sectors with similar characteristics to those found in previous studies.

\footnotetext{
${ }^{17}$ We have also estimated a version of the model using these data where experience and experience squared were not included in the switching equation. There too the hypothesis of free choice was rejected (See Dickens and Lang 1985b).
} 
Further, nearly all workers would earn more in the primary sector than in the secondary sector. The test for barriers between the non-union primary and secondary sector confirms their existence - particularly for blacks. Thus the existence of queues for primary jobs in our previous work is not solely the result of our including union members in our sample.

Finally, these tests are only as good as our distributional assumptions. If there are substantial departures from normality in the distribution of the unobservables, then the tests are invalid. In this regard the goodness of fit test described above is quite encouraging. That the implied distribution of wages from the model, assuming normality for the errors, fits the true distribution so well suggests that the normality assumption may be a good one.

\section{A Reply to Some Critics}

Heckman and Hotz (1986), while presenting findings consistent with the dual market view for Panamanian males, have criticized our work as being uninformative. They make four specific points: 1) that there may be more than two sectors so the test for free choice may be invalid because the model is misspecified, 2) that we do not adequately account for nonpecuniary differences between the sectors, 
3) that because of costs to mobility between the sectors, the decision rule for sector choice is misspecified, and 4) our assumption of joint normality of the unobservables in the model may be incorrect. They also note 'in passing' that the likelihood ratio statistic we use to test the null hypothesis of only one sector is not theoretically valid. As noted in footnote 3 of our 1985a paper and in footnote 7 above, despite the theoretical problem defining the disttibutfon of the test statistic, Monte Carlo evidence cited in Goldfeld and Quandt (1976) suggests our approach provides a conservative test of the null hypothesis. Given the size of the test statistic relative to this apparently conservative critical value (well over fifty times the .01 significance level), the data overwhelmingly reject the restrictions of the single market model. The exact distribution of the test statistic simply is not an issue here.

As Heckman and Hotz note, points 1, 2 and 4 were all discussed in the 1985a paper. Point 3 is wrong. The version of the model we tested in our 1985a paper assumed that there were sector specific skills and thus costs to mobility. Above we have replicated that test as well as one which assumes no costs to mobility. Nonetheless, the more general criticism that the choice model may be misspecified is valid. The estimation of a more complicated model which allowed for limited transferability of skills between sectors proved intractable. 
Points 1 and 2 have no bearing on our first concern .- whether the dual market model provides a better description of the wage distribution than the standard single market model. Point 4 does, and as described above, we (Dickens and Lang, 1987) subjected our original model to a goodness of fit test and showed that not only do we fail to reject the distributional assumptions at the .05 level, but also that the dual market model significantly outperforms a complex single sector model with a very general error distribution and one more parameter.

All four points are of more concern to the interpretation of the test of free choice. Heckman and Hotz, in their second point, claim that our tests require us to assume that race and schooling have no effect on tastes for secondary employment. In fact, we argue on the basis of auxiliary evidence that more educated workers and blacks are likely to have a greater preference for primary employment. This expectation is not confirmed. In any case, our 1985a paper notes that an alternative interpretation of our test is that blacks, more educated workers, or both prefer secondary jobs. More generally, their arguments can be interpreted as saying that the null hypothesis of free choice may be rejected either because it is false or because of errors in the empirical specification or the auxiliary hypothesis used to derive the theoretical prediction. We accept this criticism, but point out that 
it is applicable to any empirical hypothesis test. It is therefore possible to reject all empirical tests as uninformative. Indeed Heckman and Hotz come close to this position when they accept that human capital theory is also untestable.

We believe that the way to view the question is not to reject the testability of theories. Instead we must recognize that no test can ever be viewed as definitive except with the hindsight of history. As we discussed above this problem is not unique to dual market theory, economics, or even the social sciences. It is always possible to reinterpret the results of any test to make them consistent with another theory. However, when a theory motivates a long string of tests and comes through them with as little need for revision as labor market segmentation theory has, the theory deserves attention. It has proved itself to be a fruitful path for research. It is not any one test, but the weight of the evidence, particularly the dynamic context of the evidence, which suggest that labor market segmentation theory deserves serious attention.

Conclusion

labor market segmentation theory has been very progressive. In the early 70 s factor analytical tests of the descriptive power of the 
segmentation perspective were remarkably successful. Most of the earty studies of differences in wage determination mechanisms were successful. Problems with inconsistency in the resutts of these studies have been shown to be due to inadequate a priori classification schemes. When the early studies were challenged for their problems with sample selectivity bias, later studies showed that even after corrections for this problem the differences in the wage determination mechanisms persist. Early empirical work showed patterns of mobilii between the sectors consistent with descriptive work. Further, in our work on dual markets we have developed considerable evidence suggesting the existing of barriers to mobility between the sectors. In response to critics we have shown that the dual market model provides a much better description of the income distribution than does a highly augmented human capital model. The examination of inter-industry wage differences in the last decade has also provided a long string of successes for the labor market segmentation perspective.

In comparison the human capital perspective has not fared Well. Although highly progressive for much of the 60 s and 70 s the human capital program has become quite regressive in recent years. The challenges of the evidence generated by the labor market segmentation perspective have left advocates of human capital theory stretching to 
explain anomalous results. Attempts to empirically verify patched versions of the theory have generally not been successful. Sample selection bias did not explain the differences in the wage determination mechanisms between the primary and secondary sectors. Helwege found that failure to control for human capital did not explain the intertemporal correlation of inter-industry wage differences. Several attempts to find evidence that inter-industry wage differences are due to unobserved ability have been unsuccessful.

The success of labor market segmentation theory both in the theoretical and empirical domain, particularly its relative success in predicting the outcome of studies undertaken in response to criticism of previous work, deserves recognition. Labor market segmentation theory should be taken seriously by economists.

What does this mean? Labor market segmentation theory should be given at least equal consideration with human capital theory when economists are analyzing policies or planning tests of economic hypothesis. What are the effects of increasing school quality on worker productivity or the effects of job training? What the welfare costs and benefits of unemployment insurance? What are the benefiis of trade and industrial policies? These questions may have markedly different answers from the two perspectives. 
The application of labor market segmentation theory to new problems will not be easy. labor market segmentation theory is still in its infancy. Much work remains to build and expand the theory. If economists are to take labor market segmentation theory seriously, they will need to develop the theory further. In particular, the nature of the wage determination mechanism in different sectors needs to be establiihed. We still face a wide range of theories which can explain inter-employer wage differences and queuing. Since they have widely diierent policy implications, it is important to sort them out.

The relation of labor market segmentation to race discrimination is another area which deserves study. Our examinations give inconsistent results on the relative importance of wage and employment discrimination in the two sectors. It would be interesting and important to understand these results. Further, extensions of the labor market segmentation model to capture the nature of women's labor markets would allow us to address more convincingly how much progress woman have made in the last two decades.

Finally, models of labor market segmentation are closely related to models of unemployment. These models are natural vehicles for examining questions about the composition and distribution of unemployment and its likely response to active labor market policies. 
However, first we need to answer some basic questions about unemployment. How much unemployment is caused by workers queuing for primary sector jobs? How much is the result of jobs churning in the secondary sector? What are the roles of layoffs and recall in the unemployment process? The development and application of labor market segmentation theory poses an exciting challenge to economists wishing to understand how the labor market works. 


\section{References}

Akerlof, George A., "Gift Exchange and Efficiency Wage Theory: Four Views," American Economic Review, 74 (May 1984): 79-83.

Averitt, Robert T., The Dual Economy, New York: Norton, 1968.

Beaudry, Paul, 'Entry Wages Signalling Future Wages: A Foundation to Turnover Models of Unemployment," Boston University, mimeo, 1990.

Beck, E.M., Horan, Patrick M., and Tolbert, Charles M. 1978. "Stratification in a Dual Economy: A Sectoral Model of Earnings Determination," American Sociological Review, 43:704-720.

Bibb, Robert, and Form, William H. 1977. "The Effects of Industrial, Occupational and Sex Stratification on Wages in Blue-Collar Markets,' Social Forces, 55:974-996.

Bliss, Christopher J. and Stern, Nicholas H., "Productivity, Wages and Nutrition, 1: The Theory," Joumal of Development_Economics, 5 (1978): 331-62.

Bowles, S. and Gintis H. 1976. Schooling in Capitalist America, Basic Books.

Buchele, Robert, 1976. "Jobs and Workers: A Labor Market Segmentation Perspective on the Work Experience of Young M $\theta \mathrm{n}$,' Unpublished doctoral dissertation, Harvard University.

Cain, Glenn. 1976. "The Challenge of Segmented Labor Market Theories to Orthodox Theory, Journal of Economic Literature, Dec., 14:12151257.

Calvo, Guillermo, 'Quasi-Walrasian Theories of Unemployment," American Economic Review, 69 (May 1979): 102-7.

Carmichael, H. Lorne, "Efficiency Wage Models of Unemployment: An Overview, Economic Inquiry, 28 (April 1990). 
Camoy, M. and Rumberger, R. 1980. 'Segmentation in the U.S. Labor Market: Its Effects on the Mobility and Earnings of Whiies and Blacks,' Cambridge Journal of Economics, 4 (June):1 17-132.

Conant, Eaton H. 1963. 'Worker Efficiency and Wage Differentials in a Clerical Labor Market,' Industrial and Labor Relations Review, 16 (April): 428-433

Dickens, William T., 'Wages, Employment and the Threat of Collective Action by Workers,' NBER working paper, 1986.

Dickens, William T., and Katz, Lawrence F. 1987a. 'Industry Wage Differences and Industry Characteristics,' in Kevin Lang and Jonathan $S$ Leonard, eds., Unemplovment and the Structure of Labor Markets, Oxford: Basil Blackwell, 1987.

Dickens, William T., and Katz, Lawrence F. 1987b. 'Industry Wage Differences and Theories of Wage Determination,' NBER Working Paper 2271.

Dickens, William T. and Lang, Kevin. 1985a. 'A Test of Dual Labor Market Theory,' American Economic Review, Sept., 75:792-805.

Dickens, William T., and Lang, Kevin. 1985b. 'Testing Dual Labor Market Theory: A Reconsideration of the Evidence,' NBER Working Paper $\# 1670$.

Dickens, William T., and Lang, Kevin. 1986. 'Labor Market Segmentation and the Union Wage Premium, NBER Working Paper, no. 1883.

Dickens, William T., and Lang, Kevin. 1987. 'A Goodness of Fii Test of Dual Labor Market Theory,' NBER Working Paper 2350.

Dickens, William T., and Lang, Kevin. 1988. 'Labor Market Segmentation and the Union Wage Premium, The Review of Economics and Statistics.

Dickens, William T., Katz, Lawrence, Lang, Kevin, and Summers, Lawrence. 1989. 'Employee Crime, Monitoring, and the Efficiency Wage Hypothesis,' Journal of Labor Economics,July. 
Edwards, Richard C. 1975. "The Social Relations of Production in the Firm and Labor Market Structure,' in Labor Market Segmentation, ed. by Richard Edwards, Michael Reich, and David M. Gordon, Lexington, MA: D.C. Heath.

Evans, Robert Jr. 1960. 'Worker Quality and Wage Dispersion: An Analysis of a Clerical Labor Market in Boston,' Industrial Relations Research Association Proceedings.

Foulkes, Fred, Personnel Policies in Laroe Nonunion Comoanies, Englewood Cliffs, N.J.: Prentice-Hall.

Friedberg, Rachel, Lang, Kevin, and Dickens, William T. 1988. 'The Changing Structure of the Female Labor Market, 1976-I 984,' IRAA 418 Annual Proceedings.

Gibbons, Robert, and Katz, Lawrence F. 1989. 'Learning, Mobilii, and Inter-Industry Wage Differences,' NBER Working Paper 3182

Goldfeld, Steven M., and Quandt, Richard E. 1976. 'Techniques for Estimating Switching Regressions,' in their Studies in Non-Linear Estimation, Cambridge: Ballinger.

Goldman; M.I. 1983. U.S.S.R. in Crisis, W.W. Norton, New York, 1983.

Gordon, David M. 1971. 'Class, Productivity and the Ghetto,' Unpublished doctoral dissertation, Harvard University.

Groshen, Erica L 1987. "Sources of Wage Dispersion: The Contribution of Inter-Employer Differentials Within

Federal Reserve Bank of Cleveland, mimeo.

Industry,'

Groshen, Erica L 1988a. Why Do Wages Vary Among Employers?

Federal Reserve Bank of Cleveland Economic Review, 1938.

Groshen, Erica L. 1988b. 'Do Wage Differences Among Employers Last?' Cleveland Fed. mimeo, April.

Harrod, Roy F., 'The Scope and Method of Economics,' Economic Journal, 48 (September 1938): 383412 
Heckman, James J. and Sedlacek, Guilherme. 1985. 'Heterogeneity, Aggregation and Market Wage Functions: An Empirical Model of Self Selection in the Labor Market,' Journal of Political Economy, Dec., 93:1 077-I 125.

Heckman, James J., and Hotz, Joseph V., 1988. 'An Investigation of to Labor Market Earnings of Panamanian Males: Evaluating theSources of Inequality," Journal of Human Resources, Fall, 21:507-542.

Helwege, J. 1987. 'Interindustry wage Dilerentials,' UCLA mimeo, Oct.

Heywood, John S., 'Imports and Domestic Wages: Is the Relationship Consistent with Expense Preference Behavior?" University of WisconsinMilwaukee, mimeo, 1990.

Hodson, Randy D. 1977. 'Labor Force Participation and Earnings in the Core, Peripheral and State Sectors of Production,' unpublished M.A. thesis, Dep. of Sociology, University of Wisconsin-Madison.

Hodson, Randy D. 1983 Workers' Eaminqs and Corporate Economic Structure. New York: Academic Press.

Holzer, Harry J., Katz, Lawrence F., and Kreuger, Alan B. 1988. 'Job Queues and Wages: New Evidence on the Minimum Wage and InterIndustry Wage Structure,' Princeton University Industrial Relations Section Working Paper 230.

Katz, Lawrence F., 1986. 'Efficiency Wage Theories: A Partial Evaluation,' NBER Macroeconomics Annual, 1986, Cambridge, MA: N] 236-276.

Kletzer, L. 1989. 'Returns to Seniority After Permanent Job LOSS,' American Economic Review, 79536543.

Koopmans, Tjalling, Three Essavs on the State of Economic Science, New York: McGraw-Hill, 1957.

Kreuger, Alan, and Summers, Lawrence. 1987. 'Reflections on the InterIndustry Wage Structure,' in Kevin Lang and Jonathan S Leonard, Unemplovment and the Structure of Labor Markets, Oxford: B a $s$ i I Blackwell, 1987. 
Kreuger, Alan, and Summers, Lawrence. 1988. "Efficiency Wages and the Inter-Industry Wage Structure,' Econometrica, 56:259-293.

Lakatos, Imre, The Methodoloov of Scientific Research Proorammes, Vol. I., Cambridge: Cambridge University Press, 1978.

Lang, Kevin, 'Persistent Wage Dispersion and Involuntary Unemployment,' Quarterly Journal of Economics, 106 (February 1991).

Lang, Kevin, and Dickens, William T. 1988. 'Sociological and Neoclassical Perspectives on Segmented Labor Markets,' in Industries, Firms, and Jobs, George Farkas and Paula England, eds., Plenum Press: New York.

Lang, Kevin, and Kahn, Shulamit. 1990. 'Efficiency Wage Models of Unemployment: A Second View,' Economic Inquiry, April, 28: 296806.

Lang, Kevin, Marquez, Gustavo, and Romaguera, Pilar, 'Theories of Wage Determination: Lessons from Chile and Venezuela,' Boston University, mimeo, 1988.

Lazear, Edward, 'The Narrowing of Black-White Wage Differentials Is Illusory,' American Economic Review, 69 (September 1979): 558-64.

Leigh, Duane E. 1976. "Occupational Advancement in the Late 1960s: An Indirect Test of the Dual Market Hypothesis,' Journal of Human Resources, 11 (Spring):1 55-171.

Leonard, Jonathan. 1989. 'Wage Structure and Dynamics in the Electronics Industry,' Industrial Relations, 28:2 (Spring): 251-275.

Lindbeck, Assar, and Snower, Dennis J., 'Wage Setting, Unemployment, and Insider-Outsider Relations,' American Economic Review, 76 (May 1986): 235-9.

Lucifora, Claudio, 1991. 'Inter-industry and Occupational Wage Differentials,' Universita' Cattolica di Milano mimeo, May.

Mars, Gerald, 1982. Cheats at Work: An Anthropoloav of Workplace Crime, London; Boston: Allen \& Unwin. 
Murphy, Kevin M., and Topel, Robert. 1987. 'Unemployment, Risk, and Earnings: Testing for Equalizing Wage Differences in the Labor Market,' in Kevin Lang and Jonathan S Leonard, eds., Unemployment and the Structure of Labor Markets, Oxford: Basil Blackwell, 1987.

Murphy, Kevin M., and Topel, Robert. 1990. 'Efficiency Wages Reconsidered: Theory and Evidence,' in Y. Weiss, ed., Advances in the Theory and Measurement of Unemployment, London: Macmillan.

Oster, Gerry. 1979. 'A Factor Analytic Test of the Theory of the Dual Economy,' Review of Economics and Statistics, 61 :33-51.

Osterman, Paul. 1975. 'An Empirical Study of Labor Market Segmentation,' Industrial and Labor Relations Review, 28:508-523.

Piore, Michael J. 1980a. 'Dualism as a Response to Flux and Uncertainity," in Dualism and Discontinuitv in Industrial Societies, ed. by Suzanne Berger and Michael J. Piore, New York: Cambridge University Press.

Piore, Michael J. 1980b. 'The Technological Foundations of Dualism,' in Dualism and Discontinuitv in Industrial Societies, ed. by Suzanne Berger and Michael J. Piore, New York: Cambridge University Press.

Rebitzer, James B. and Taylor, Lowell J. 1991. 'A Model of Dual Labor Markets When Product Demand is Uncertain,' Quarterlv Journal of Economics, 106 (November).

Robertson, Dennis, Essavs in Monetary Theory, London: King, 1940.

Rosenberg, Samuel. 1976. 'An Empirical Test of the Dual Labor Market Hypothesis,' unpublished manuscript, Williams College.

Rosenberg, Samuel. 1980. 'Male Occupational Standing and the Dual Labor Market,' Industrial Relations, 193449.

Salop, Steven C., 'A Model of the Natural Rate of Unemployment,' American Economic Review, 69 (March 1979): 117-25.

Schiller, Bradley R. 1977. 'Relative Earnings Mobility in the United States,' American Economic Review, 74: 433-444. 
Shapiro, Carl and Stiglitz, Joseph E., 'Equilibrium Unemployment as a Worker Discipline Device,' American Economic Review, 75 (June 1984): 43344.

Slichter, S., 1950. 'Notes on the Structure of Wages,' Review of Economics and Statistics, Feb., 80-91.

Smith, James P., 'Career Wage Mobility,' in Steven Shulman and William Darity, Jr., eds., The Question of Discrimination, Middletown, CT: Wesleyan University Press, 1989.

Solow, Robert, 'Another Possible Source of Wage Stickiness,' Journal of Macroeconomics, 1 (1979): 79-82.

Stiglitz, Joseph E., 'The Efficiency Wage Hypothesis, Surplus Labor, and the Distribution of Income in LD.C.s,' Oxford Economic Papers, 28 (1976): 185-207.

Tolbert, Charles M., Horan, Patrick M., and Beck, E.M. 1980. 'The Structure of American Economic Segmentation: A Dual Economy Approach,' American Journal of Sociology, 85:1095-I 116.

Wachter, Michael L 1974. 'Primary and Secondary Labor Markets: A Critique of the Dual Approach,' Brookings Papers on Economic Activii 3: 637680.

Weiss, Andrew. 1980. 'Job Queues and Layoffs in Labor Markets with Flexible Wage Expectations,' Journal of Political Economics, June, 88: 526538.

Weiss, Andrew, Models of Unemployment, Lavoffs, and Waae Dispersion, Princeton: Princeton University Press, 1990.

Weitzman, Martin, 'A Theory of Wage Dispersion and Job Market Segmentation,' Quarterly Journal of Economics, 104 (February 1989): 12138.

Wial, Howard J. 1988. 'The Transition from Seconadary to Primary Employment: Jobs and Workers in Ethnic Neighborhood Labor Markets,' unpublished MIT doctoral dissertation. 
Yellen, Janet L. 1984. 'Efficiency Wage Models of Unemployment,' American Economic Review Papers and Proceedings, 74: 200-205.

Zucker, Lynne G., and Rosenstein, Carolyn. 1981. 'Taxonomies of Institutional Structure: Dual Economy Reconsidered,' American Sociological Review, 46:869-884. 
TABLE 1

PARAMETER ESTIMATES FOR SINGLE AND DUAL

LABOR MARKET MODELS

\begin{tabular}{|c|c|c|c|c|}
\hline \multirow[b]{2}{*}{ VARIABLE OLS } & \multirow[b]{2}{*}{ COEF. } & \multicolumn{3}{|c|}{ SWITCHING MODEL } \\
\hline & & PRIMARY & SECONDARY & SWITCHING \\
\hline CONSTANT & $\begin{array}{c}0.730 \\
(0.014)\end{array}$ & $\begin{array}{r}0.720 \\
(0.086)\end{array}$ & $\begin{array}{r}1.146 \\
(0.107)\end{array}$ & $\begin{array}{l}-0.315 \\
(0.137)\end{array}$ \\
\hline SMSA & $\begin{array}{r}0.109 \\
(0.004)\end{array}$ & $\begin{array}{r}0.078 \\
(0.018)\end{array}$ & $\begin{array}{l}-0.330 \\
(0.030)\end{array}$ & $\begin{array}{r}0.445 \\
(0.035)\end{array}$ \\
\hline $\begin{array}{l}\text { NEVER } \\
\text { MARRIED }\end{array}$ & $\begin{array}{l}-0.106 \\
(0.007)\end{array}$ & $\begin{array}{l}-0.057 \\
(0.027)\end{array}$ & $\begin{array}{c}0.397 \\
(0.048)\end{array}$ & $\begin{array}{l}-0.577 \\
(0.006)\end{array}$ \\
\hline SCHOOL & $\begin{array}{c}0.069 \\
(0.001)\end{array}$ & $\begin{array}{r}0.077 \\
(0.001)\end{array}$ & $\begin{array}{r}0.005 \\
(0.006)\end{array}$ & $\begin{array}{c}0.018 \\
(0.007)\end{array}$ \\
\hline WHITE & $\begin{array}{c}0.158 \\
(0.007)\end{array}$ & $\begin{array}{r}0.127 \\
(0.023)\end{array}$ & $\begin{array}{l}-0.321 \\
(0.045)\end{array}$ & $\begin{array}{r}0.515 \\
(0.054)\end{array}$ \\
\hline EXPERIENCE & $\begin{array}{c}0.030 \\
(0.001)\end{array}$ & $\begin{array}{c}0.030 \\
(0.002)\end{array}$ & $\begin{array}{l}-0.025 \\
(0.005)\end{array}$ & $\begin{array}{r}0.048 \\
(0.006)\end{array}$ \\
\hline $\begin{array}{l}\text { EXPERIENCE } \\
\text { SQUARED } / 100\end{array}$ & $\begin{array}{c}-0.046 \\
(0.001)\end{array}$ & $\begin{array}{l}-0.041 \\
(0.005)\end{array}$ & $\begin{array}{r}0.066 \\
(0.010)\end{array}$ & $\begin{array}{l}-0.107 \\
(0.012)\end{array}$ \\
\hline $\begin{array}{l}\text { STANDARD } \\
\text { ERROR }\end{array}$ & 0.418 & 0.347 & 0.772 & * \\
\hline $\begin{array}{l}\text { COVARIANCE } \\
\text { WITH SWITCH- } \\
\text { ING ERROR }\end{array}$ & & -0.028 & 0.775 & - \\
\hline $\begin{array}{l}\text { LOG LKE- } \\
\text { LIHOOD }\end{array}$ & -26467 & & 25283 & \\
\hline
\end{tabular}

*The standard error of the switching equation is normalized to one. Figures in parentheses are standard errors. 


\section{TABLE 2 \\ COMPOSITION OF INDUSTRY EMPLOYMENT}

INDUSTRY

Agriculture, forestry and fisheries

Mining

Construction

Nondurable Manufacturing

Food and Kindred Products

Tobacco

Textile Mill Products and Apparel

Paper and Allied Products

Printing, Publishing and Allied Ind.

Chem., Petrol., Coal, Rub., and Plastic

Leather and Leather Products
Secondary ? Primary

$25.29 \quad 36.39 \quad 38.32$

$\begin{array}{lll}207 & 8.64 & 89.29\end{array}$

$3.75 \quad 13.12 \quad 83.13$

$\begin{array}{lll}5.60 & 16.50 & 77.90\end{array}$

$8.52 \quad 13.80 \quad 77.90$

$6.97 \quad 26.11 \quad 66.92$

$\begin{array}{lll}227 & 7.11 & 90.62\end{array}$

$\begin{array}{lll}7.83 & 11.12 & 81.05\end{array}$

$2.78 \quad 10.33 \quad 86.91$

$12.35 \quad 30.70 \quad 56.95$

Durable Manufacturing

$\begin{array}{llll}\text { Lumber, Wood and Furniture } & 9.33 & 26.14 & 64.53\end{array}$

Stone, Clay, Glass and Concrete Prod. $\quad 3.59 \quad 14.92 \quad 81.49$

Primary Metals

$\begin{array}{lll}2.26 & 7.20 & 90.54\end{array}$

Machinery and Equipment

$\begin{array}{lll}242 & 7.74 & 89.84\end{array}$

Transportation

$6.27 \quad 10.53 \quad 83.20$

Communications (except telephone)

$9.69 \quad 15.52 \quad 74.79$

Utilities and Telephone

$1.40 \quad 5.01 \quad 93.59$

Wholesale

$6.94 \quad 14.50 \quad 78.56$

Retail (except eating, drinking and liq.) $\quad 13.35 \quad 21.60 \quad 65.06$

Eating \& drinking places, liquor stores $\quad 29.29 \quad 3211 \quad 38.60$

Finance, Insurance and Real Estate

$\begin{array}{lll}7.06 & 11.73 \quad 81.20\end{array}$

(continued) 
TABLE 2 (cont.)

INDUSTRY

Secondary ? Primary

Business and Repair Services

$\begin{array}{llll}\text { Advertising, Research and Computers } & 275 & 6.05 & 91.21\end{array}$

Services to Bldgs and Personnel Supply 24.21 $24.12 \quad 51.67$

$\begin{array}{llll}\text { Detectives and Protective Services } & 48.66 & 17.83 & 33.51\end{array}$

$\begin{array}{llll}\text { Repair and Services in N.E.C. } & 8.35 & 20.31 & 71.34\end{array}$

Personal Services

$23.94 \quad 26.88 \quad 49.18$

$\begin{array}{llll}\text { Entertainment and Recreational Services } & 18.75 & 22.91 & 58.34\end{array}$

Professional and Related Services

Offices of Health Professionals

$\begin{array}{lll}9.69 & 7.05 & 83.26\end{array}$

Hospitals and Health Services N.E.C. $\quad 11.33 \quad 18.04 \quad 70.63$

Nursing, Child and Residential Care

Education and Related Institutions

26.61

$2209 \quad 51.30$

Other Professional Services

15.51

15.29

69.19

2.79

5.78

91.43 
COMPOSITION OF EMPLOYMENT BY OCCUPATION

OCCUPATION

Managers and Professionals (except

those below)

Therapists and Physicians' Assistants

Post-Secondary Teachers and Librarians

Economists*

Other Teachers

Social, Recreational and

Religious Workers

Wriiers, Artists, Entertainers and Athletes
Secondary ? Primary

$\begin{array}{lll}3.44 & 5.63 & 99.73\end{array}$

$11.61 \quad 16.34 \quad 71.65$

$9.73 \quad 7.53 \quad 62.74$

$\begin{array}{lll}0.00 & 4.71 & 95.29\end{array}$

$19.15 \quad 16.11 \quad 64.74$

$36.41 \quad 29.16 \quad 43.43$

$\begin{array}{lll}7.54 & 11.06 & 61.37\end{array}$

Technical, Sales and Administrative

Support Occupations

$\begin{array}{llll}\text { Health Technologists and Technicians } & 5.69 & 15.67 & 76.44\end{array}$

Technologists and Technicians Except

Health Sales

$\begin{array}{lll}2.10 & 6.95 & 90.95\end{array}$

Retail

Other Than Retail

$22.66 \quad 23.61 \quad 53.72$

$6.66 \quad 11.67 \quad 61.65$

Administrative Support

Super., Comp. Op. and Secretaries

Information Clerks

$\begin{array}{lll}4.23 & 11.65 \quad 64.13\end{array}$

Messengers, Office Machine Operators, Mail, Rate, Personnel, Library and

Bookkeeping Clerks

Bank Clerks

Other

$19.24 \quad 17.99 \quad 63.76$

Service Occupations

Protective Services (except guards)

$\begin{array}{lll}16.94 & 0.99 & 63.96\end{array}$

Guards

$\begin{array}{lll}39.05 & 22.67 & 36.06\end{array}$

Food Preparation and Service

$34.29 \quad 34.07 \quad 31.64$

Health Service Occupations

Cleaning, Household and Personal

Services

$23.94 \quad 44.93 \quad 31.13$

$24.61 \quad 26.09 \quad 47.31$

*Based on small number people in occupation. 
TABLE 3 (cont.)

OCCUPATION

Secondary ? Primary

Farm, Forestry and Fishing Occupations $27.42 \quad 37.57 \quad 35.01$

Precision Production, Craft and

Repair Occupations

Mechanics and Repairers

$\begin{array}{lll}3.72 & 13.05 & 83.23\end{array}$

Construction Supervisors

$\begin{array}{lll}2.10 & 6.22 & 91.68\end{array}$

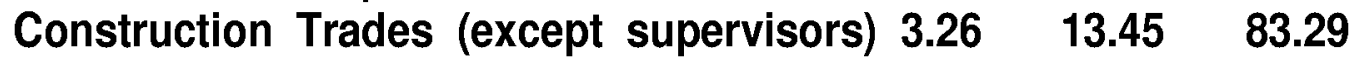

Extractors, Plant and System Operators,

Craft Supervision and Inspection and

Metal Crafts

Other Precision Production

$\begin{array}{lll}2.07 & 7.38 & 90.55\end{array}$

$5.14 \quad 19.15 \quad 75.70$

Operatives (except textile, apparel

and furnishings)

$\begin{array}{lll}4.33 & 15.09 \quad 80.58\end{array}$

Operatives (textile, apparel and

furnishings)

$9.60 \quad 36.98 \quad 53.42$

Transportation and Material Moving

Occupations

Motor Vehicle Operators

Rail and Water Transportation

$\begin{array}{lll}10.08 & 19.68 & 70.24\end{array}$

Material Moving Equipment Operators

$\begin{array}{lll}5.46 & 8.45 & 86.09\end{array}$

$\begin{array}{lll}3.99 & 15.74 \quad 80.27\end{array}$

Handlers, Equipment Cleaners, Helpers, and Laborers

Garage Workers, Vehicle Washers

and Packers

$20.07 \quad 39.39 \quad 40.55$

Others

$10.56 \quad 21.82 \quad 67.62$ 


\section{TABLE 4}

\section{COMPARISON OF DUAL LABOR MARKET CLASSIFICATION SYSTEMS}

BECK, HORAN AND TOLBERT (1978) INDUSTRIAL CLASSIFICATION

Core

Periphery

$\begin{array}{ccc}\text { SECONDARY } & ? & \text { PRIMARY } \\ 4.97 & 10.63 & 84.39 \\ 14.19 & 22.66 & 63.14\end{array}$

BIBB AND FORM (1977) INDUSTRIAL CLASSIFICATION

Core

$\begin{array}{ccc}\text { SECONDARY } & ? & \text { PRIMARY } \\ 3.38 & 10.04 & 88.58 \\ \text { il. } 29 & 17.37 & 71.32\end{array}$

HODSON (1977) INDUSTRIAL CLASSIFICATION

$\begin{array}{lccc} & \text { SECONDARY } & ? & \text { PRIMARY } \\ \text { Core } & 3.05 & 9.68 & 87.27 \\ \text { Periphery } & 1202 & 18.42 & 69.56 \\ \text { State } & 1.33 & 6.01 & 92.66\end{array}$

TOLBERT, HORAN AND BECK (1980) INDUSTRIAL CLASSIFICATION

Core

Periphery

\section{SECONDARY ? PRIMARY}

$\begin{array}{lll}3.52 & 9.69 & 86.80\end{array}$

$14.98 \quad 21.97 \quad 63.03$

OSTERMAN (1975) OCCUPATIONAL CODING SYSTEM

$\begin{array}{lccc} & \text { SECONDARY } & ? & \text { PRIMARY } \\ \text { Upper Tier, Primary } & 8.81 & 8.32 & 82.87 \\ \text { Lower Tier, Primary } & 5.48 & 12.31 & 82.21 \\ \text { Secondary } & 20.42 & 27.77 & 51.81\end{array}$


Figure 1. Hypothetical Scatter Plot--

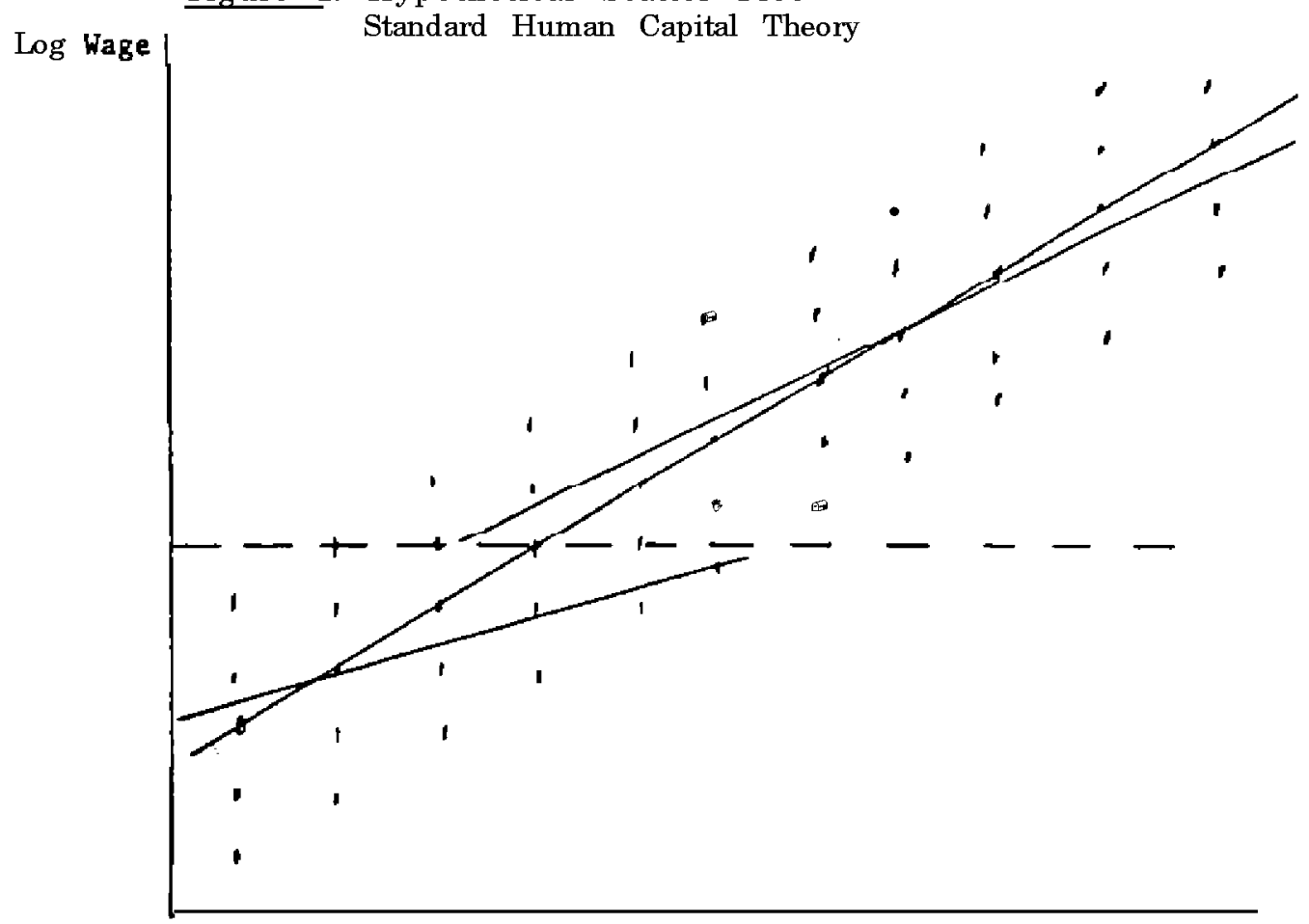

Education

Figure 2. Hypothetical Scatter Plot--

Log Wage

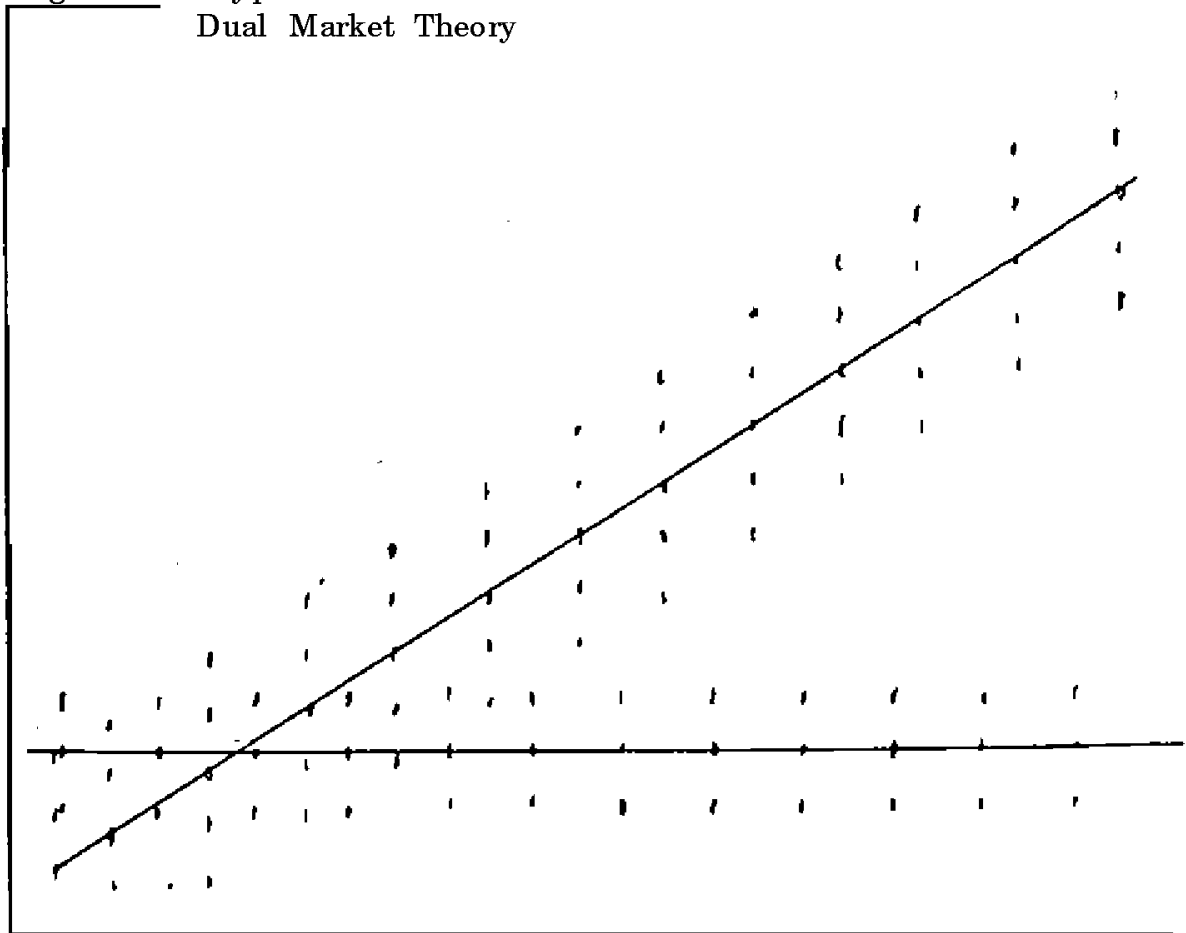

Education 


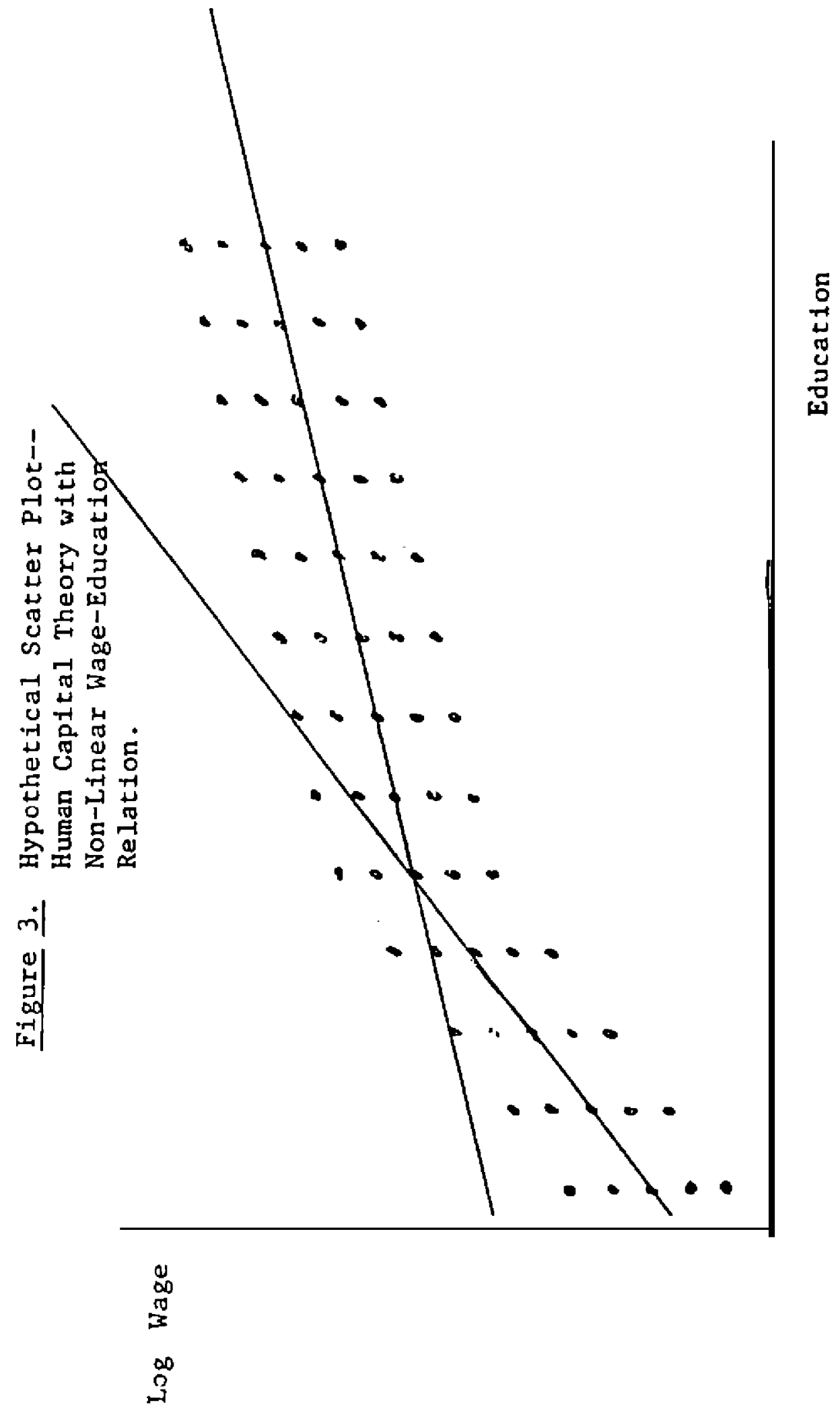

